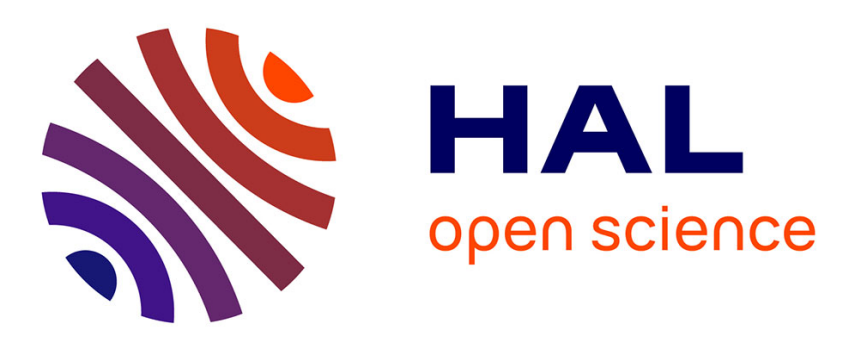

\title{
From novice to disciplinary expert: Disciplinary identity and genre mastery \\ Dacia Dressen-Hammouda
}

\section{To cite this version:}

Dacia Dressen-Hammouda. From novice to disciplinary expert: Disciplinary identity and genre mastery. English for Specific Purposes, 2008, 27, pp.233-252. 10.1016/j.esp.2007.07.006 . hal-01011832

\author{
HAL Id: hal-01011832 \\ https://hal.uca.fr/hal-01011832
}

Submitted on 24 Jun 2014

HAL is a multi-disciplinary open access archive for the deposit and dissemination of scientific research documents, whether they are published or not. The documents may come from teaching and research institutions in France or abroad, or from public or private research centers.
L'archive ouverte pluridisciplinaire HAL, est destinée au dépôt et à la diffusion de documents scientifiques de niveau recherche, publiés ou non, émanant des établissements d'enseignement et de recherche français ou étrangers, des laboratoires publics ou privés. 


\title{
From novice to disciplinary expert: Disciplinary identity and genre mastery
}

\author{
Dacia Dressen-Hammouda
}

\begin{abstract}
A student's emerging genre mastery is a complex process which involves learning not only relevant discoursal forms, but also a wide range of specialist knowledge frames. Recent research suggests that these knowledge frames are acquired during the development of a student's disciplinary identity. Although disciplinary identity clearly contributes to expert genre production, the relationship between the two has to date been relatively underexplored by EAP and ESP scholars. This paper presents a framework that describes how disciplinary identity may be structurally related to the specialist genres students must learn. A case study then examines how one geology student's developing disciplinary identity allowed him to gradually produce a key written genre in geology with increasing expertise. The study suggests that the specialist frames he embodied within his disciplinary identity enabled him to make increasing reference to geology's central concerns and practices, via a typified set of implicit textual cues. Expert writers use these implicit cues to situate themselves and their level of expertise with respect to their community of practice. In conclusion, it is argued that genre-based courses should also include instruction about both the target discipline's specialist knowledge frames as well as the implicit cues that help readers and writers reconstruct them.
\end{abstract}

\section{Introduction}

In recent years, the genre approach has been used to respond to an increasing number of pedagogical issues, including how best to facilitate access to the academic community by NSE and NNSE writers. Indeed, "moving into the academy," getting over the barriers past the discipline's "gate-keepers" (Berkenkotter \& Huckin, 1995) and into a relatively closed disciplinary community has long been an important subject of research and reflection in EAP and ESP. To this end, scholars have described the expert genres students must learn, such as the scientific research article, the abstract, or the literature review (Bittencourt-Santos, 1996; Swales, 1990; Swales \& Lindemann, 2002; Yakhontova, 1998). Others have described the genres students must produce on their way into the disciplinary community, such as the Masters thesis or the Doctoral dissertation. While some have looked specifically at these genres' linguistic and rhetorical structure (Bunton, 1999; Paltridge, 2002; Shaw, 2000), others have explored the related chain of genres students must also learn to master (Swales, 2004).

One aspect of genre mastery that has remained relatively underexplored among EAP and ESP practitioners is the role disciplinary identity plays in this process, despite a number of studies urging us to explore this relationship further. Ivanic (1998), for example, has argued that knowing how to reproduce written academic norms is not an issue of literacy as much as it is one of identity, where students struggle as writers because they are also struggling to learn the beliefs and practices of their disciplines. In contrast, experienced writers use their disciplinary knowledge pragmatically to "construct a credible representation of themselves and their work, aligning themselves with the socially shaped identities of their communities" (Hyland, 2002, p. 1091). Through the features of the disciplinary voice they have taken on, experienced writers allow other specialists to reconstruct their disciplinary identity and determine their level of expertise (Matsuda \& Tardy, 2007). In this context, Schryer and Spoel's (2005) argument that genre mastery and the development of a professional identity are closely related comes as no surprise. Clearly, genre mastery is not simply a matter of learning the genres. 
That genre knowledge includes more than knowledge about textual structures can be appreciated in the work of a growing number of genre scholars today (Berkenkotter \& Huckin, 1995; Devitt, 2004; Fairclough, 1992; Freedman \& Medway, 1994; Swales, 2004). Swales (2004, p. 21), for example, suggests that students must gain more than knowledge about just genres when he notes that graduate students and junior researchers over time must gain "a more nuanced and exact set of understandings of their genre sets". What exactly this "nuanced and more exact understanding" is goes to the very heart of genre mastery. In effect, students who are learning to master the genres of their disciplines must also necessarily acquire knowledge about the "processes" of genre production (Fairclough, 1992) that allow expert genre users to successfully use the discipline's genres. It will be argued here that knowledge about these processes emerges only as students become like the experienced practitioners with whom they are communicating. Gaining specialized knowledge of a disciplinary community's genres and mastering them presupposes taking on the discipline's identity.

The purpose of this paper is to discuss the issue of disciplinary becoming, which is the process by which students become recognized as members of a new disciplinary community. By going through this process, students gain their "disciplinary voice" (Matsuda \& Tardy, 2007) and come to master the genres of their new disciplinary community, thereby moving from novice status to that of disciplinary expert.

Specifically, the paper presents a framework that describes how the emergence of disciplinary identity coincides with genre mastery. The framework is informed by the results of a situated genre study of fieldwork writing in geology (Dressen, 2002a). ${ }^{1}$ Among its many uses, situated genre analysis can also be used as a method to answer a number of questions relative to genre mastery and the emergence of disciplinary identity. What, for example, must be learned in addition to genres that allows students to master the discipline's genres? How does the construction of a disciplinary identity contribute to genre mastery?

The paper begins by describing the framework, synthesizing aspects from identity theory, frame theory, and genre theory. A case study then examines the genre mastery of one NNSE student in geology. The framework shows that in order for the student to successfully communicate like a field geologist in English, he must first learn a whole range of normalized disciplinary frames for perceiving, interpreting and behaving. At the same time, he must also master the implicit textual cues that activate these frames for other disciplinary specialists. Finally, implications for ESP/EAP teaching will be discussed.

\section{A theory of identity}

The framework describes disciplinary identity by building on the concept of habitus (Bourdieu, 1984). For Bourdieu, one's social, and by extension disciplinary, identity arises because the social structures that characterize a particular social milieu have been unconsciously embodied within habitus. An individual's habitus unconsciously incorporates the patterns, norms and regularities that structure a social milieu: its behavioral codes, habits, bodily attitudes and ways of talking. As habitus embodies these normalized structures over time, the individual begins to perform them through her or his own bodily attitudes.

The term embodiment implies of course that the social structures and norms reflected in habitus are learned by the body. For Lakoff and Johnson (1999, pp. 17-19), people must use their bodies to create and recreate internalized social structures because the sensorimotor structure of their brains naturally causes them to identify the patterns and regularities of their environments. As they are exposed to these patterns and norms, they assimilate them as largely unconscious structures in their sensorimotor system and later perform them using their bodies: talking, doing and behaving. The bodily performance of these embodied patterns serves to anchor them as increasingly belonging to particular communities of practice.

\footnotetext{
${ }^{1}$ This situated genre analysis included (1) a genre-based study of the linguistic and rhetorical devices geologists use to talk about their fieldwork in the research article, (2) a socio-historical analysis of their field practices, (3) an ethnography-oriented study of their current field practices, (4) an interview-based textography of modern field writing practices, and (5) a recontextualization study of the writing practices of one geologist from field study (field notebook) to scientific publication.
} 
Habitus thus provides a socially structured explanation for the formation of a disciplinary identity. One's disciplinary identity is an ensemble of socio-historical regularities and norms that practitioners embody as a result of specializing within their disciplines.

\section{Frame theory}

The embodied patterns that organize knowledge about the world are frequently described by linguists as frames, or cognitive knowledge structures that capture what is typical about the world (Minsky, 1975). Today, frame is generally used among linguists to explain the non-linguistic processes by which individuals cognitively organize the world.

Frame has particular relevance to talking about the embodied structures of habitus and disciplinary identity. Indeed, linguistic descriptions of frame (Fillmore, 1985; Stubbs, 2001; Tannen, 1993; Tannen \& Wallet, 1993; Yule, 1996) closely overlap with that of habitus (Bourdieu, 1984). Like the structures of habitus, frames are not seen as being innately present in the individual, but are acquired through socialization. Like habitus, frames are constructed out of cultural and social experience and are both diachronic and culturally dependent (Tannen, 1993; Tannen \& Wallet, 1993; Yule, 1996). Once established, frames, like habitus, are relatively stable, with some features being more stable than others (Lakoff \& Johnson, 1999; Stubbs, 2001). Furthermore, recent work in cognitive linguistics suggests that, like habitus, the construction of a frame is a process that occurs largely beyond our conscious control and is therefore inscribed in the knowledge of the body (Goodwin, 2000; Lakoff \& Johnson, 1999). Frames describe how and why we recognize recurrent patterns in our social environments and later perform those patterns to make relevant meaning.

Consequently, habitus, or disciplinary identity, can also be described as an ensemble of specialized embodied frames. These frames are specific to people's specialized communities of practice and shape their ways of seeing, thinking, believing, doing and communicating in common.

\section{Genre theory}

The concept of frame, with its normalizing nature and capacity to capture the prototypical features of shared situations, is also of particular relevance to talking about genres. It is revealing that many genre scholars today treat genres as a sort of frame:

Genres are not just forms. Genres are forms of life, ways of being. They are frames for social action. They are environments for learning. They are locations within which meaning is constructed. Genres shape the thoughts we form and the communications by which we interact. Genres are the familiar places we go to create intelligible communication action with each other and the guideposts we use to explore the familiar. (Bazerman, 1997, p. 19)

As a kind of frame, a genre does not ensure that a typified, communicative act effectively be carried out but provides the potential for doing so. Other similarities between frames and genres are further underscored in the literature. Both have been described as

1. being socially situated, emerging as a shared response to the exigencies of a group interaction (Bazerman, 1994; Berkenkotter \& Huckin, 1995; Miller, 1984; Tannen \& Wallet, 1993; Yule, 1996);

2. having typified as recognizable patterns as a result of individuals proposing consistent responses to recurrent situations (Lakoff \& Johnson, 1999; Minsky, 1975; Stubbs, 2001; Swales, 1990; Tannen, 1993);

3. being relatively stable yet only momentarily so. Both can be modified - however slowly - in response to changing needs and perceptions (Atkinson, 1999; Bazerman, 1988; Lakoff \& Johnson, 1999; Minsky, 1975; Schryer, 1993; Stubbs, 2001);

4. being historically and culturally situated, developing in response to group practices over time (Atkinson, 1999; 
Bazerman, 1988; Salager-Meyer, 1998; Tannen \& Wallet, 1993; Yule, 1996);

5. being dialogically transmitted by competent users to newcomers who thus learn socially relevant ways of organizing experience (Anderson, Reder, \& Simon, 1998; Ericsson, 1996; Freedman \& Medway, 1994; Lakoff \& Johnson, 1999; Russell, 1997; Schryer \& Spoel, 2005);

6. providing for cognitive efficiency by translating the relevant elements of shared experience into discernible structures (Anderson et al., 1998; Berkenkotter \& Huckin, 1995; Lakoff \& Johnson, 1999; Russell, 1997);

7. being rhetorical actions that organize the modalities and conditions of peoples' interactions with one another (Devitt, 2004; Goodwin, 2000; Medway, 2002; Miller, 1984; Roth, 2004);

8. being meaningless in isolation from their 'semiotic chain'. It is the properties of the chain that give meaning to each (Goodwin, 2000; Hindmarsh \& Heath, 2000; Ra ïsa nen, 2002; Roth, 2004; Swales, 2004; van Leeuwen, 1999). Frames and genres might thus be taken to describe largely similar phenomena of patternization.

Significantly, a number of studies (Devitt, 2004; Goodwin, 2000; Hindmarsh \& Heath, 2000; Roth, 2004; van Leeuwen, 1999) in fact suggest that a discipline's shared frames may be indispensable to genre instantiation. For example, the discourse used by archeologists to classify color in the field is successful only because it draws on a wide range of shared semiotic frames. Without the contribution of semiotic frames (e.g., recognizable bodily gestures or specialized graphic signs identified in the environment), the language used to negotiate the disciplinary task would lack specialized meaning. A whole range of semiotic frames (e.g., graphic signs, gesture, discourse) must be juxtaposed in order for the communicative interaction to become dense with specialist meaning (Goodwin, 2000, p. 1490).

The juxtaposition of an entire range of semiotic frames to communicate meaningfully is also seen in "discoursal silences" (Huckin, 2002; Swales, 2004), where propositional content is communicated without being explicitly stated. Roth (2004), for example, has observed that shared frames of perception allow for silent communication. In his study of workers in a salmon hatchery, he demonstrated that frames of perception, as shared semiotic resources, played a large role in allowing workers to successfully mark salmon according to size with coded-wire tags and to discard those that were too small without talking, despite potential conflicts between workers over how best to categorize the fish and how to signal when the fish were not of the correct size for the chosen category (Roth, 2004, p. 1038).

In this regard, the specialized semiotic frames people embody as part of their disciplinary or professional identity represent much more than just the background knowledge or context to using their community's genres. They in fact provide the structural content for the normalized communicative interaction (see also Devitt, 2004, pp. 25-32). In this sense, interactive meaning making is distributed not only across verbal modes, but simultaneously across verbal, perceptual, gestural and other semiotic modes. The expression of one semiotic form, such as a genre of text, thus closely depends on the simultaneous elaboration of other shared semiotic resources in order for it to acquire a specialist meaning.

The strong association between genres and the embodied frames of disciplinary identity implies they are linked within a 'semiotic chain' similar to the chain of genres shown to be necessary for carrying out specialist activities within a community of practice (e.g., Bazerman, 1994; Räisänen, 2002; Swales, 2004). In this regard, to demonstrate genre mastery students must learn to reproduce not only the relevant genre chain(s) of their community of practice but also its entire chain of shared semiotic resources in which their common experiences have patternized as frames.

Supposing that embodied frames and genres largely depict similar processes of patternization, one might develop the metaphor of the genre chain further by describing embodied frames as the symbolic genres of the semiotic chain. They are symbolic because they are the unexpressed patterns for seeing, interpreting, knowing or being that individuals come to embody within their disciplinary identity and share as a result of collectively carrying out the activities of their community. Practitioners rely on these symbolic genres to elaborate the visible materialized genres - linguistic, visual, graphic, gestural, or behavioral - they use 
to communicate with one another. Symbolic and materialized genres must co-occur within the discipline's semiotic chain of genres and both must contribute to the specialized activity in order for that activity to become densely meaningful for specialists.

Therefore, in order for students to write like specialists, their disciplinary identity must first embody the symbolic genres of their discipline so as to be able to reproduce the materialized genres of their discipline. To highlight this semiotic interdependency, throughout the remainder of this paper 'materialized genre' will refer to the genres studied and taught by EAP and ESP scholars (e.g., research grants, scientific research articles, book reviews, conference presentations, etc.) whereas 'symbolic genre' will be taken to refer to the cognitive frames that organize disciplinary knowing and being. Students must have learned all types of genre in order to demonstrate genre mastery and write like they 'belong'.

\section{Geology's symbolic genres}

Because the ultimate purpose of this framework is to describe what, in addition to materialized genres, a student in field geology must learn in order to become a recognized member of the disciplinary community, at this point it would be useful to summarize some of the symbolic genres experienced academic field geologists use to carry out their work, both in and out of the field. These symbolic genres have been identified based on previous interviews with geology researchers about the ways of perceiving and knowing valued by their community of practice (Dressen, 2002a).

Geologists' symbolic genres range across a number of semiotic fields and include knowledge about disciplinary behavior as well as shared attitudes and practices. They are the historically sedimented structures of the discipline's history - its ways of being, seeing, interpreting, behaving and thinking - that are passed down from one generation of field geologists to the next, partly in the classroom and through outside reading but especially during yearly field trips during which students intensely interact with their instructors and the structures they encounter in the field. Over time, students as emerging practitioners come to share the discipline's symbolic genres as similar ways of being, seeing and acting together:

- self-identification: how field geologists see or feel themselves as being similar to other field geologists;

- attitude: how the ways field geologists evaluate their work is alike;

- practices and doing: how their practices in the field are similar;

- seeing and professional vision: how what they see in the field is similar;

- interpreting: how what they understand from natural phenomena is similar.

Some of the symbolic genres geology students must learn thus organize their attitudes about being geologists. Novice geologists quickly learn that going out into the field is hard, physical labor and that they must be prepared to endure all possible contingencies: mud, scorching heat, icy rain, week-long or month-long hikes, tens of kilos of rock samples to carry each day, possible falls and injury, effects of high altitude, shortage of food, wild animals or hostile locals. These experiences shape the attitudes they have not only toward the discipline but also toward themselves, causing them to develop a feeling of 'otherness' as they increasingly identify with other members of geology's "brethren of the hammer" (Rudwick, 1985, p. 41).

Field geology's symbolic genres also organize its practitioners' shared practices. Thus, novice geologists must learn not only to measure correctly, follow outcrops or pick up rocks, but also master their discipline's shared ways of seeing and interpreting field structures. These symbolic genres include knowing how to see the field and make relevant observations, knowing how to identify a particularly 'good' example of an outcrop, as well as knowing how to interpret natural field facts within the 
discipline's current frames of interpretation.

As a result of their hands-on experience and growing camaraderie with their instructors, novice field geologists gradually come to embody these symbolic genres within their disciplinary identity, or habitus (Bourdieu, 1984). Gaining familiarity and expertise in using these symbolic genres is an essential part of learning how to reproduce the discipline's materialized genres in increasingly expert and relevant ways, as will be seen below.

\section{Showing expertise: linking symbolic and materialized genres in the field account}

Producing an experienced geologist's report of fieldwork in the field account thus requires drawing on the discipline's symbolic genres. The field account is a part-genre geologists publish as part of the scientific research article that describes their fieldwork observations and interpretations (Dressen, 2003). Clearly, as in all genre mastery, mastering this part-genre includes knowing how to wield the appropriate discoursal forms - knowing how to say the right thing the right way at the right time. But this mastery also implies the ability to draw on the discipline's shared symbolic genres. By drawing on the discipline's symbolic genres to construct their field account, experienced writers succeed in constructing credible representations both of themselves (e.g., Hyland, 2002; Matsuda \& Tardy, 2007) and of their field expertise.

Of course, the ways in which field writers unequivocally demonstrate disciplinary membership and expertise in the field account are neither straightforward nor obvious. Indeed, experienced writers of the field account do not make explicit comments about their expertise and disciplinary identity, but reconstruct them in their texts using largely implicit cues. These implicit textual cues are important for novices to learn because their skillful wielding will later allow them to express their expertise to other informed specialists.

What makes these implicit cues particularly difficult for uninitiated students to master, however, is that they are not easily apparent, as can be appreciated in the following passage:

The Koolen Lake-Lavrentiya Bay region (Figures 2,3, and 4) exposes a sequence of sillimanite-grade to second-sillimanite-grade granitic gneisses, paragneisses, schists, amphibolites, and marbles that are intruded by a heterogeneous suite of plutons, stocks, dikes, and sills. The metamorphic rocks constitute the core of a large (100 km across) structural culmination flanked on all sides by lower-grade Paleozoic and Mesozoic metasedimentary rocks and Cretaceous volcanic rocks; all are intruded by Cretaceous granitic rocks (Figure 2). (Bering Strait Geologic Field Party, 1997)

Clearly, one could analyze this specialist discourse and teach its complex noun phrases, its theme/rheme structure, or its verb types. The argument being made here, however, is that specialist discourse communicates far more than what the non-specialist can perceive at the surface of the text. Notably, disciplinary specialists communicate hidden propositions that 'speak to', or activate, other specialists' knowledge of their discipline's symbolic genres.

Until students are able to grasp the hidden expressions of disciplinary expertise and the implicit mechanisms that allow for it, they cannot truly 'master' the field account part-genre even if they are able to proficiently manipulate its discoursal forms. Sure enough, geology students quickly learn that in the field account, they are to use a particular 'jargon' to state measurements and observations made in the field. However, until they are also able to reframe the materialized description of their field research by linking it to the discipline's symbolic genres, their fieldwork descriptions will not show the characteristics of expert description, for only this linking will give their descriptions full disciplinary relevance.

\section{Using implicit cues to show disciplinary expertise}

How do experienced writers draw on shared symbolic genres to demonstrate expertise? A corpus analysis 
of 103 research articles (1996-1999) from three subfields in geology (geochemistry, petrology, and structural geology) shows that experienced writers use a typified set of low-level textual cues in the field account that make implicit reference to geology's symbolic genres (see Appendix A for results of the linguistic analysis). These cues cluster around three rhetorical moves (Dressen, 2002a, 2003). Examples of the three moves given below are taken from Merle, Cobbold, and Schmid (1989):

Move 1: Showing explicit researcher implication in the research account, whereby authors draw overt attention to their physical activity in the field:

a. agent-centered statements about researcher activity in the field

"We have also observed definite sheath folds in oblique sections."

b. adjectives and adverbs of judgment marking researchers' intellectual activity

"Kinematic indicators are less clear and abundant in rocks..."

"... the HTD lineation is flat lying, often pitching gently E, but sometimes even gently W."

c. interpretative comments supported by field observations

"As one approaches the northern steep belt near Airolo, both lineation and foliation acquire step attitudes, suggesting that they have become folded together..."

Move 2: Providing disguised indications of researcher activity in the field by signaling authors' field activities - but without necessarily drawing explicit attention to their person:

d. nominal indications of the researcher's activity in the field

"Geological mapping of stretch lineations (Fig. 7), shear indicators (Fig. 8a, b) and other structures reveal late ductile deformations..."

e. verbal indications of the researcher's activity in the field

"The main lineation observed in the Pennine zone..."

"This structure seems to track the direction of maximum total stretch."

f. metric, angle and direction measurements

"... further $\underline{E}$, where the lineation is nearly vertical, or in the Domodossola area, where it now pitches at about $45^{\circ} E . "$

g. locational adverbs and prepositions of researcher movement in the field

"Small scale HTD shear indicators ... show an apparent uplift of southern units with respect to northern units along the vertical stretch lineation (Fig. 10)."

h. metadiscoursal references to visual data summarizing field results

"If we compare the attitude of foliation and lineation (see Figs. 1, 2 and 4)..."

i. geographical location markers

"One is in the Monteo Rosa unit at Villadossola, near Domodossola..."

j. references to one's own prior field publications

"North of the Simplon subdome, the senses of shear associated with the retrograde stretching lineations (depicted in Fig. 6) are reversed between the Berisal synform and the Glishorn antiform (Fig. 1) (Mancel and Merle 1987, Fig. 8)."

Move 3: Demonstrating disciplinary membership using specialist terminology:

$\mathrm{k}$. nominal and adjectival descriptive qualifiers of the field

"Even in the anomalous Maggia steep zone, this radial pattern of flat lying lineations is not disturbed, the lineations following the strike of the steep zone."

1. indications of geological age

"Either the HTD lineation formed in a flat lying E-W attitude, or it became reoriented during later events as a result of superimposed ductile deformation (strain)."

$m$. technical verbal adjectives and participles

“... the HTD lineation is flat lying, often pitching gently E, but sometimes even gently W. If the foliation is restored to the horizontal by rotating about the E-W strike, the lineation remains $\mathrm{E}-$ W."

n. references to others' fieldwork

"Backfolds postdate well developed biotites which have been dated at 15 Ma. Steiger and Bucgher, 1978, Ramsay in Steck et al., 1979)."

These cues and moves, which often all cluster together within a single sentence, demonstrate the writer's 
disciplinary expertise because they link back to the discipline's symbolic genres. They do so by implying information about the writer's disciplinary identity and level of expertise which can then be inferred by other disciplinary experts. As seen in Table 1 below, these textual cues and their implicit propositions evoke the symbolic genres described in the previous section.

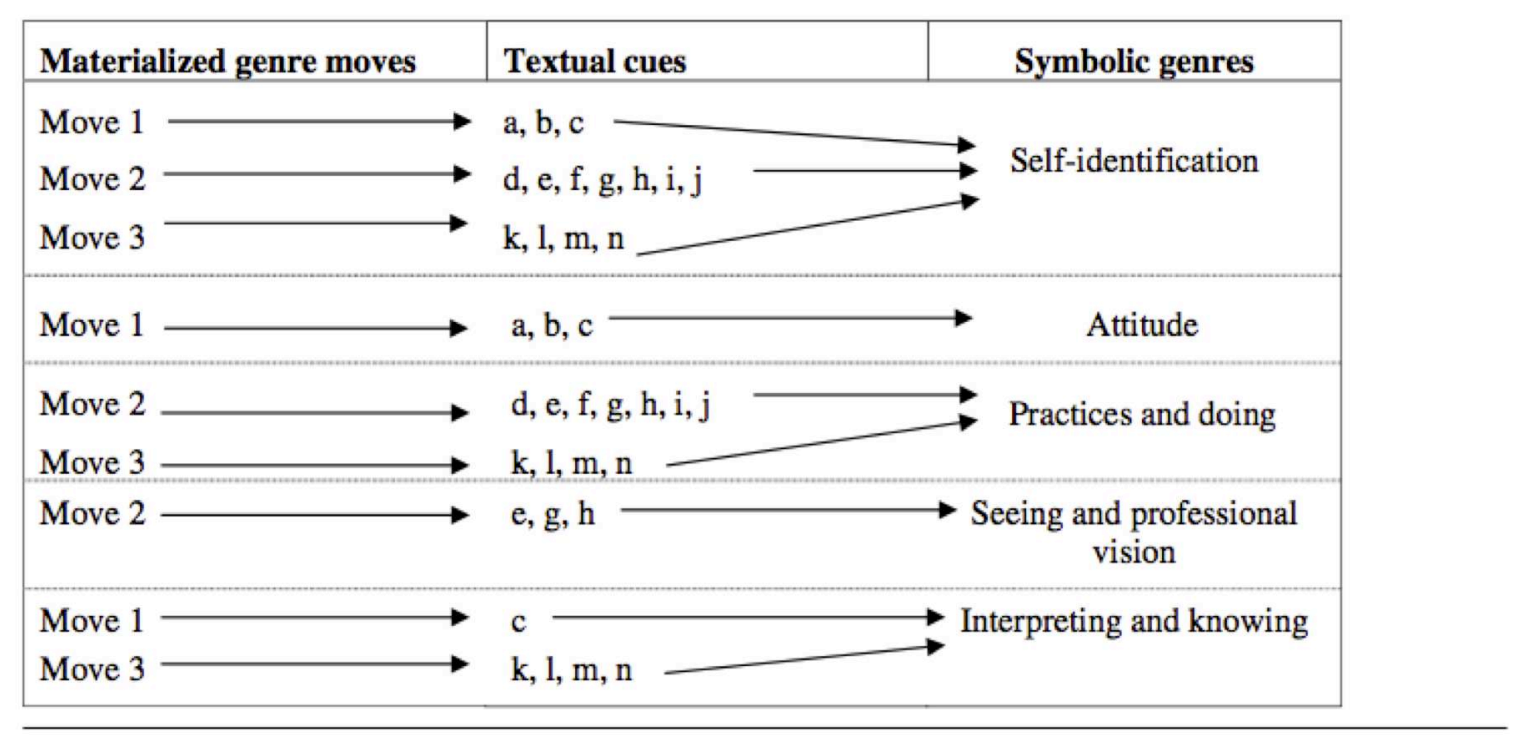

Table 1. Using implicit textual cues to link materialized and symbolic genres

Knowing how to reproduce and manipulate the insider meaning implied but not explicitly stated in the field account part-genre sets the experienced practitioner apart from the novice-as-outsider. The failure to use the cues successfully causes students' texts to only vaguely resemble an expert's account of field research, as we will see in the next section. Until she or he has intimate knowledge about the community's entire semiotic chain of genres for seeing, understanding, behaving and communicating, someone who wants to become a geologist, like the student described in the next section, will continue to write 'not quite' like an experienced geologist. This is because the student's developing disciplinary identity, or habitus (Bourdieu, 1984), does not yet embody all the discipline's semiotic genres that would enable him to carry out and write about specialist tasks in ways relevant to disciplinary practitioners.

The student who is the focus of the following case study was originally an informant in the interview study cited earlier (Dressen, 2002a). As I traced the recontextualization of Patrick' ${ }^{2}$ doctoral fieldwork study from field notes to published research article (Dressen, 2002b), I quickly became caught up not only in how he was successfully learning to use his discipline's materialized genres but also in the development of his disciplinary identity which manifested itself in the very ways he was learning to 'talk the talk' of the field geologist.

Below we will examine his growing mastery of the field account over a period of six years. We will first examine his field writing as a third-year undergraduate in geology, then as a first-year Masters student, and finally as a third-year doctoral student. We will observe the emergence of the expert implicit cues described in the preceding section in his field writing over time. The appearance of these cues in his writing marks not only his mastery of the field account part-genre, but also his entry into a community of specialists.

\footnotetext{
2 'Patrick' is a pseudonym.
} 



\section{Results and discussion: learning to master the discipline's genres}

Text 1. The first text is an excerpt from a field account Patrick wrote as a third-year undergraduate student at a local French university. The cues found in this text can be taken as indirect evidence for the development of his disciplinary identity. The text, originally in French, has been translated; sentence numbers have been added.

\footnotetext{
${ }^{1}$ The Montagne Noire, southern extension of the French Massif Central, and the Cap Creus peninsula, extension of the Alberes crystalline massif into Spanish territory, are two fragments from the Hercynian ridge. ${ }^{2}$ In both cases, the terrains are old, having formed during the Carboniferous era. ${ }^{3}$ The field trip allowed us to study the region's deep tectonics [visual 1]. ${ }^{4}$ Using the poles from the stratification planes, we trace a large circle onto the Schmidt net [visual 2]. ${ }^{5}$ The polarity from the Schmidt net gives us the fold axis ' $\mathrm{x}$ ' (N40.NE6). ${ }^{6} \mathrm{By}$ using the poles from the schistosity planes, we determine a mean pole (e) with which we trace the medial schistosity plane (N44-NW34). ${ }^{7}$ We note that there is a slight variation in schistosity direction in the two limbs, which indicates to us a fan-shaped schistosity. ${ }^{8}$ The Schmidt net allows us to conclude that the schistosity plane passes through the fold axis.
}

Here, only a handful of the cues we would expect to find in an experienced geologist's field account can be seen. There are, for example, a few move-3 devices (' $k$ ') that describe the geological field: 'crystalline massif' and 'ridge' [1]; 'terrains' [2]; 'deep tectonics' [3]; 'stratification planes' [4]; 'schistosity' and 'fanshaped schistosity' [5-8]; 'limbs' [7]. Patrick demonstrates further knowledge about disciplinary practices by referring to frames of geological interpretation (move-3, 'l'): 'Hercynian' [1]; ' . . old, having formed during the Carboniferous era' [2]. He provides other proof that he is aware of disciplinary practices by using two move- 2 devices to describe measurements he made in the field: 'N40.NE6' [5] and 'N44NW34' [6]. Other features of this text also show that Patrick has begun to adopt the field geologist's persona, as seen in his multimodal text which balances ties to both visual and interpretive genres, seen for example in his use of data observation to draw inferences:

s.7 We note that there is a slight variation in the direction of schistosity in the two flanks, which indicates to us a fanned schistosity...

s.8 The Schmidt net allows us to conclude that the schistosity plane passes through the fold axis.

Typically, all these cues would imply that the writer identifies her or himself as a geologist and has at least some knowledge about the discipline's symbolic genres that inform the geologist about how to do fieldwork and how to interpret what is seen.

This, however, is the extent to which this student uses the part-genre's expert move strategies and textual cues at this point. Indeed, even his purpose in using the cues is quite different from that of a more experienced field geologist, who would strive to 'disappear' from the field account so as to make the rocks "speak for themselves" (Dressen \& Swales, 2000). Instead, Patrick tells about what he did rather than to describe a natural reality. As he writes:

s.3 The field trip allowed us to study...

s.4 ... we trace a large circle on the Schmidt net...

s.5 The polarity ... gives $u s$ the fold axis...

s.6 By using the poles from the schistosity planes, we determine a mean pole with which we trace...

s.7 We note that there is a slight variation...

Even when he appears to be addressing disciplinary concerns with specialist jargon, i.e., 'the Schmidt net' [5], he is really only giving a narrative of how he found the right answer, instead of making that answer simply 'emerge' from his field observations ('The polarity from the Schmidt net gives us the fold axis ' $x$ ' (N40.NE6)' [5] or 'By using the poles from the schistosity planes, we determine a mean pole...' [6]).

While his early student writing thus shows some evidence of the part-genre's expected textual cues, what 
is implied by the cues diverges from the way in which more experienced writers would use them. Clearly, Patrick's purpose here is less the need to inscribe his findings within a larger bed of community knowledge than to demonstrate to his professors that he has correctly carried out the assigned field exercises.

When recently thinking back on this early and in his words "unsuccessful" field trip, Patrick confided that he had had an extremely hard time writing up the field account because he did not know what he was supposed to be understanding in the field (P. Gonçalves, p.c., 2006). As we will see, this is a shift he adeptly made over the next couple of years.

Text 2. The second excerpt is taken from a field account Patrick wrote at the end of the first year of his Masters degree. Here we will see that while there are a good deal more of the types of textual cues expert field geologists use to imply their field competence and disciplinary expertise, his use of the cues still signals his novice status. The excerpt, originally in French, has once again been translated; sentence numbers have been added.

${ }^{1}$ Four large lithological formations succeed one another from west to east:

$-{ }^{2}$ The western unit or Collobrières series consists of thick schistous or sandstone-schistous formations with interstratifications of quartzite and a leptyno-amphibolite group.

- ${ }^{3}$ The Bormes gneisses are covered by the western unit to the west and are delimited to the east by the GardeFreinet and Grimaud throws. ${ }^{4}$ They are considered to be orthitederived, resulting from the transformation of an older intrusive aluminiferous granite of which a few relics subsist (Barral metagranite). ${ }^{5}$ One can also note the presence of micaschistous levels within the gneiss.

$-{ }^{6}$ The Garde-Freinet unit is located geographically between the two throws cited above, and structurally under the Bormes gneiss. ${ }^{7}$ From a lithological point of view, one essentially encounters orthogneisses associated with micaschists and migmatites.

$-{ }^{8}$ The lower migmatitic gneisses correspond to the eastern part of the formation: they constitute the SainteMaxime and Saint-Tropez massifs, as well as the greater part of the Tanneron massif (extension toward the north of Maures)... ${ }^{9}$ Amphibolites associated with leptynites, metagabbros or serpentinites are present in the four formations described above:

- ${ }^{10}$ In the Collobrières series a leptyno-amphibolite complex has been interpreted as derived from a differentiated series of alkaline basalt type ! alkaline trachyte (sic).

- ${ }^{11}$ In the lower migmatitic gneiss and the Garde-Freinet unit, amphibolite layers of a tholeitic nature are generally migmatised. ${ }^{12}$ They are always associated with small serpentinite blocks (case of sample MAU5) as well as with gabbros. ${ }^{13}$ On the basis of their structural position at the interface between the two layers of differing lithology, these layers have been interpreted as sills or basalt veins.

- ${ }^{14}$ The amphibolites intercalated in the Bormes gneiss are not abundant and form 10-m wide lentils in the gneiss.

In the first half of the field account, Patrick summarizes results from Seyler's (1986) field study. He proficiently synthesizes the essential parts of Seyler's publication, using numerous move- 3 cues (' $k$ ') to describe the study (e.g., lithological, schistous, sandstone, interstratifications, quartzite, leptynoamphibolites, gneiss, throw, orthite, intrusive, aluminiferous granite, massifs [1-8]). Among these move-3 cues, he intercalates several move- 2 cues ('e', 'f', 'g', and 'i') which imply that Seyler carried out his own field research:

s.1 Four large lithological formations succeed one another from (g) west to east (f)...

s.2 ...the western unit or Collobrières (i) series...

s.3 ... the Bormes (i) gneisses are covered by the western (g) unit to the west $(g+f)$ and are delimited to the east $(g$ $+\mathrm{f}$ ) by the Garde-Freinet and Grimaud (i) throws.

s.6 ...the Garde-Freinet (i) unit is located (e) geographically between (g) the two throws cited above, and structurally under $(\mathrm{g})$ the Bormes (i) gneiss.

Patrick's summary of Seyler's study suggests he has gained knowledge about the symbolic genres that structure fieldwork practices and vision. His knowledge of these symbolic genres tells him what he should 
write about, a type of know-how he lacked in his earlier text. Here he describes the composition of geological structures and the relationships between them.

In the second half of the excerpt [9-14], Patrick then describes his own fieldwork. In sentence 10, Patrick begins to describe his own field study, using frequent move-3 cues (' $\mathrm{k}$ ' and ' $\mathrm{m}$ ') as a basis for this description:

$\mathrm{s} .10$ In the Collobrières series $(k)$ a leptyno-amphibolite $(k)$ complex $(k)$ has been interpreted as derived from $(m)$ a differentiated $(m)$ series $(k)$ of alkaline basalt type $(k) \rightarrow$ alkaline trachyte $(k)$.

Intercalated among these move-3 descriptive cues are several move- 2 cues ('d', 'e', 'f', 'g', 'i',) and a couple of move- 1 cues ('b', 'c'). The more frequent combination of all these cues contrasts with his previous text, causing his writing at this point to more closely resemble that of an experienced field writer, as shown by the results of corpus analysis (see Appendix A). Throughout the following discussion of Patrick's writing strategies, move- 3 cues will be indicated by italics, move- 2 cues by underlining, and move- 1 cues by bold-faced print:

$\mathrm{s} .10$... a leptyno-amphibolite $(k)$ complex $(k)$ has been interpreted as $(\mathbf{c})$ derived from $(\mathrm{m})$ a differentiated $(\mathrm{m})$ series $(k) \ldots$

$\mathrm{s} .11 \ldots \underline{\mathrm{in}}(\mathrm{g})$ the lower migmatitic gneiss $(k)$ and the Garde-Freinet(i) unit $(k)$, amphibolite layers $(k)$ of a tholeitic nature $(k)$ are generally $(\mathbf{b})$ migmatised $(m)$.

s.12 They are always (b) associated with(e) small (b) serpentinite blocks(k) (case of sample MAU5 (d)) as well as with $\operatorname{gabbros}(k)$.

$\mathrm{s} .13$ On the basis of $(\mathbf{c})$ their structural position $(k)$ at the interface between $(\mathrm{g})$ the two layers $(k)$ of differing $(m)$ lithology $(k)$, these layers $(k)$ have been interpreted as (c) sills $(k)$ or basalt veins $(k)$.

$\mathrm{s.14}$ The amphibolites $(k)$ intercalated $(\mathrm{m})$ in $(\mathrm{g})$ the Bormes $(\mathrm{i})$ gneiss $(k)$ are not abundant $(\mathbf{b})$ and form $(\mathrm{m}) \underline{10-\mathrm{m}}$ wide (f) lentils( $k$ ) in (g) the gneiss( $k$ ).

In this second text, then, Patrick is clearly a 'bit more' of a geologist because he shows he is more proficient in wielding the part-genre's materialized resources. His emergent identity is implied by a more frequent and conventional use of the field account's textual cues than seen in his earlier field writing. As a result, his writing allows the reader to make inferences about his mastery of the discipline's symbolic genres, such as his ability to critically evaluate the field (move-1 ' $b$ ' $[11,12,14])$. The cues also show him to be relatively well-versed in the discipline's practices of doing fieldwork (move-2: ' $d-g$ ' + ' $i$ ' and move$3:$ ' $\mathrm{k}$ ', ' $\mathrm{m}$ ' [10-14]). He also demonstrates that he knows he must draw on interpretive genres to understand what he has observed (move-1 interpretive cues, 'c' $[10,13])$. Therefore, not only does he use more of the part-genre's textual cues, he also uses them in such a way that their implicit propositions more conventionally activate the links to the discipline's symbolic genres. His use of the part-genre's implicit cues can be taken as indirect evidence that, by this time, he has begun embodying the geology's symbolic genres within his disciplinary identity and is able to use them to communicate more meaningfully to disciplinary practitioners.

At the same time, however, the way in which Patrick combines these cues is at times atypical and exposes his continued novice status and incomplete mastery of the discipline's semiotic genre chain. For example, he uses a number of non-standard textual devices that are unexpected in more experienced writing (e.g., 'basalt type ! alkaline trachyte' [10] or 'case of sample MAU5' [12]). In particular, given the importance of interpretation for the discipline, we would expect that he always provide support for his interpretations using field observations. In spite of this, he sometimes fails to explain why the field was interpreted the way it was [e.g., 10]. To the contrary, the interpretation is simply stated as a given, without support:

s.10 ... a leptyno-amphibolite $(k)$ complex $(k)$ has been interpreted as $(\mathbf{c})$ derived from $(m)$ a differentiated $(m)$ series $(k) \ldots$

We would expect for it to be contextualized by other move- 1 and move- 2 devices, showing that his interpretation is objectively grounded in field 'reality'. Without the reasoning behind his interpretation, 
however, Patrick fails to lay claim over and justify it, shortcomings easily avoided by a more experienced writer. These difficulties can be taken as further indirect evidence for the still ongoing development of his disciplinary identity. As a result of not fully mastering the symbolic genre of interpretation and not fully weighing its importance for the disciplinary community, Patrick is less successful in using the part-genre's resources to communicate what he should see and understand in the field.

Finally, his field account plays it 'safe'. There is no reading between the lines needed here, no skillful wielding of the implicit cues used to purposefully control the rhetorical effects the account will have on the reader. At this point, Patrick is still concerned primarily with showing his instructors that he has understood the field rather than trying to convince other scientific readers that his interpretation is the most plausible or closest to natural reality. As a result, his use of the implicit cues does not yet fully reflect the entire range of implicit propositions that allow field geologists to establish their credibility and authority within the community. This positioning changes, however, in the final text that we will examine now.

Text 3. In this final text, Patrick is nearing the end of his doctoral dissertation. He has by this point carried out a substantial, month-long field study in Madagascar that forms the basis for his dissertation research. He has presented papers on his findings and has written them up for publication. Moreover, he has begun putting distance between himself and his dissertation advisors by arguing for the inclusion of certain field details that he considers key to supporting his interpretational framework. His advisors argued against their inclusion in the article submitted to, and later published in, a special issue of Precambrian Research on African plate tectonics (Gonc alves, Nicollet, \& Lardeaux, 2003), contending that they were unimportant. Patrick stubbornly held onto his field data and had his version accepted by the journal's review committee (Dressen, 2002b). The following account was written directly in English (sentence numbers were added).

${ }^{1}$ In the low strain zones, where the D2 strain is moderate, the L1 stretching lineation, marked by biotite or amphibole, define a regular east-west trending, perpendicular to the Andriamena basement contact, with a pitch around $90^{\circ}$ and a variable plunging due to the F2 folding (Fig. 3b-stereo a, b, c). ${ }^{2}$ In the high strain zones, where the $\mathrm{S} 1$ foliation is verticalized, the L1 lineations are steeply plunging due to their passive rotation during the F2 folding (Fig. 3b-stereo d). ${ }^{3}$ Near Brieville, where a transposition of S1 into a new S2 occurs, the L1 lineation seems to be replaced by a new L2 subhorizontal lineation broadly oriented N170 (Fig. 3b-stereo e).

${ }^{4}$ Structures related to the D1 deformation can be observed more easily outside the high strain zones D2. ${ }^{5}$ At the outcrop scale, we observe numerous isoclinal intrafolial folds with a hinge parallel to the L1 lineation and a sub-horizontal axial plane (Fig. 3b-stereo a, b, c and Fig. 5). ${ }^{6}$ The initially horizontal S1 foliation is also affected by boudinage structures compatible with the E-W stretching lineation direction (Fig. 5). ${ }^{7}$ All these structures suggest that the D1 event underwent a significant amount of vertical shortening. (Gonçalves et al., 2003)

In this final text, Patrick has definitively taken on the field geologist's voice and disciplinary identity, at least at a "junior researcher" level (Swales, 2004), as witnessed by the high cue density without any trace of the propositional ambiguity seen earlier. In contrast to his earlier field writing, his disciplinary status has also changed because he has now begun presenting his field observations and interpretational claims to the wider disciplinary community rather than just to his instructors. The rhetorical effort involved in having his claims accepted by the disciplinary community is reflected in the lexical density of his fieldwork description, as seen in his substantial use of move-3 cues [1-2]:

s.1 In the low strain zones $(k)$, where the $D 2(l) \operatorname{strain}(k)$ is moderate, the $L 1(l)$ stretching $(m)$ lineation $(k)$, marked by biotite $(k)$ or amphibole $(k)$, define a regular east- west trending $(m)$, perpendicular to the Andriamena basement $(k)$ contact $(k)$ with a pitch $(k)$ around $90^{\circ}$ and a variable plunging $(m)$ due to the $F 2(l)$ folding $(m)$ (Fig. 3b-stereo a, b, c).

s.2 In the high strain zones $(k)$, where the $S 1(l)$ foliation $(k)$ is verticalized $(m)$, the $L 1(l)$ lineations $(k)$ are steeply 
plunging $(m)$ due to their passive rotation $(k)$ during $(l)$ the $F 2(l)$ folding $(m)$ (Fig. 3b-stereo d).

In these first two sentences, he similarly uses a fair number of move-1 ('b', 'c') and move-2 cues (' $\mathrm{f}$ ', 'g', ' $h$ ', 'i') that unequivocally situate his activity in the field, which has important implications for establishing his credibility as the doer of his own fieldwork:

s.1 In (g) the low strain zones, where the D2 strain is moderate (b), the L1 stretching lineation, marked by (e) biotite or amphibole, define(e) a regular (b) east-west(f) trending, perpendicular to $(\mathrm{g})$ the Andriamena(i) basement contact with a pitch around (b) $\underline{90^{\circ}}$ (f) and a variable (b) plunging due to (c) the F2 folding (Fig. 3b-stereo a, b, c) (h).

$\mathrm{s} .2$ In (g) the high strain zones, where the S1 foliation is verticalized, the L1 lineations are steeply (b) plunging due to (c) their passive (b) rotation during the $\mathrm{F} 2$ folding (Fig. 3b-stereo d) (h).

The dense interweaving of these cues also allows Patrick to 'explicitly' imply that he has mastered the specialized subject matter of his discipline, that he is able to critically evaluate what is before him in the field ('b'), that he knows how to carry out all the work of the field geologist ('e', 'f', 'g', 'i') and that he knows how to observe correctly ('e', 'g', 'h').

To be recognized as a geologist with expertise, however, he must not only be able to observe but also interpret what he sees. He begins to do this in sentence 3, where he situates his work's locale (near Brieville) and describes an interpretation (the L1 lineation seems to be...), which he backs up with the timely use of concrete fieldwork evidence: move-2 measurements (' $\mathrm{f}$ '), locational adverbs (' $\mathrm{g}$ '), and visual data ('h'):

s.3 Near (g) Brieville (i), where a transposition $(k)$ of $S 1(l)$ into (g) a new (b) $S 2(l)$ occurs, the L1(l) lineation( $k$ ) seems to be replaced (c) by a new (b) subhorizontal $(\mathrm{g})$ L2(l) lineation $(k)$ broadly (b) oriented $(m)$ N170 (f) (Fig. 3b-stereo e) (h).

His observational difficulties ('seems to be replaced') are resolved in the following sentence where he notes that structures supporting his interpretation 'can be observed more easily' outside of the first zone [4]. He then states which field structures support this claim [5-6]:

s.4 Structures $(k)$ related to $(m)$ the $D 1(l)$ deformation $(k)$ can be observed(e) more easily (b) outside(g) the high strain zones $(k) D 2(l)$.

s.5 At the outcrop scale (g), we observe (a) numerous (b) isoclinal intrafolial folds $(k)$ with a hinge $(k)$ parallel to $(\mathrm{g})$ the L1(l) lineation $(k)$ and a subhorizontal $(\mathrm{g})$ axial plane $(k)$ (Fig. 3b-stereo a, b, c and Fig. 5) (h).

s.6 The initially $(1)$ horizontal $(\mathrm{g}) S 1(l)$ foliation $(k)$ is also (b) affected by $(m)$ boudinage structures $(k)$ compatible with (b) the E-W(f) stretching $(m)$ lineation direction $(k)$ (Fig. 5) (h).

In support of his interpretation, and for the first time attested in the samples of his field writing, Patrick uses a very rare move-1 strategy ('a', see Appendix A) to draw explicit attention to his role as a researcher ('At outcrop scale,we observe numerous isoclinal intrafolial folds...' [5]). Given its rarity, its use provides undeniable rhetorical evidence for the claim being made: because an author attaches her or his 'person' to the field evidence, it must be taken to be true. Patrick's use of this overt move-1 strategy becomes even more revealing when we consider that sentences 5 and 6 also contain the contested field details his advisors wanted him to do away with, as was mentioned earlier ('Fig. 5' and 'boudinage structures'). The field details described in 5 and 6 thus become his pie'ces de re'sistance in the build up toward his interpretation, which he provides in the final sentence of the section:

s.7 All (b) these structures ( $k$ ) suggest that (c) the D1 event ( $l$ ) underwent ( $m$ ) a significant amount (b) of vertical $(\mathrm{g})$ shortening $(\mathrm{m})$.

Implying that he is now a field geologist with expertise, Patrick's use of the part-genre's materialized cues allows his interpretation to 'speak for itself', causing it to emerge from the constructed reality of the field. However, the apparent ease with which he does this belies an intense rhetorical effort to make his account 
appear as though it were the only reading possible. Given his extensive use of the cues, it is almost as if he has endeavored to leave the reader (and his instructors?) with no other choice but to accept his interpretation. In using the part-genre's implicit textual cues, he resolutely constructs his disciplinary identity and level of expertise for readers. He has thus moved beyond a simple use of the surface features of the text, as disciplinary novice, to a more sophisticated handling of field evidence that allows him to be definitively identified, and published, as a member of the "brethren of the hammer" (Rudwick, 1985).

\section{Conclusion}

The purpose of this article has been to illustrate how more than formal discoursal knowledge about materialized genres is needed to write like a disciplinary expert. Indeed, the process of disciplinary coming shows us how students, like Patrick, must master an entire semiotic genre chain that underlies their discipline's specialist activity in order to begin writing like specialists.

Experienced writers rely on the structured, symbolic genres embodied within their habitus to construct credible representations of their disciplinary competence. They do this by skillfully wielding typified sets of textual cues that carry implicit propositions. These implicit propositions signal membership and competence to initiated insiders, in ways likely similar to those found by Matsuda and Tardy (2007) in their study of how blind reviewers respond to cues in the text in order to reconstruct writers' disciplinary identity and levels of competence and expertise. The use of such cues activates disciplinary practitioners' background knowledge about the identity, attitudes, practices, vision and interpretation they may - or may not - share with the writer. It has been argued here that only mastery of the entire semiotic genre chain underlying a disciplinary activity will allow students to move beyond writing like novices to reproducing the sort of complex rhetorical positioning characteristic of more experienced writers. It is this complex rhetorical positioning, and its linking to symbolic genres through implicit cues, that distinguishes the less experienced from the experienced writer.

The case study presented here has provided many reasons why a genre-based course in EAP/ESP should teach more than just the discipline's materialized genres by also including instruction about the target discipline's symbolic genres. Indeed, students typically lack the types of knowledge that would allow them to reproduce materialized genres with greater expertise. The framework presented in this paper is one attempt to explain what else students must learn before being able to demonstrate greater disciplinary expertise in their writing. It provides a further argument for linking writing courses to disciplinary content and practices.

This paper has also argued that students must learn about the conventionalized implicit cues that link materialized and symbolic genres. Because the textual cues associated with genre mastery often carry an implicit propositional content that is not conveniently 'marked on the page', they present a particular problem for inexperienced writers. While Patrick appears to have had little trouble in picking up on the field account's implicit cues, an ongoing study shows that for other, more experienced NNSE researchers, reconstructing these implicit cues in English is not as simple as may have been suggested here. Such "discoursal silences" are therefore a highly relevant topic for further research in EAP/ESP. 


\section{Appendix A. Move and cue frequency across geology's subdisciplines}

\begin{tabular}{|c|c|c|c|c|c|c|}
\hline & \multicolumn{3}{|c|}{ Avg. \# cues per text } & \multicolumn{3}{|c|}{ Frequency of cue (in \%) } \\
\hline & $\underline{\mathrm{GC}}$. & $\underline{\mathrm{P}}$. & $\underline{\mathrm{SG}}$. & $\underline{\mathrm{GC}}$. & $\underline{\mathrm{P}}$. & $\underline{\text { SG. }}$ \\
\hline Avg. \# of cues per FA & 279.78 & 269.89 & 814.14 & 0.55 & 0.47 & 0.48 \\
\hline Move 1 cues & 26.94 & 22.21 & 64.86 & 0.05 & 0.04 & 0.04 \\
\hline Move 2 cues & 63.5 & 65.84 & 230 & 0.12 & 0.12 & 0.14 \\
\hline Move 3 cues & 170.89 & 181.84 & 519.29 & 0.33 & 0.32 & 0.31 \\
\hline \multicolumn{4}{|l|}{ Avg. \# of words in FA, per subdiscipline } & 515.39 & 569.63 & 1686.14 \\
\hline \multicolumn{7}{|l|}{ MOVE 1 CUES } \\
\hline a. Agential statements in the field & 0.22 & 0.16 & 1.75 & 0.00 & 0.00 & 0.00 \\
\hline b. Evaluative adjectives and adverbs & 22.06 & 17.47 & 46.29 & 0.04 & 0.03 & 0.03 \\
\hline c. Interpretive comments & 4.67 & 4.58 & 16.82 & 0.01 & 0.01 & 0.01 \\
\hline \multicolumn{7}{|l|}{ Move 2 CuES } \\
\hline d-e. Nominal and verbal activity & 11.72 & 13.05 & 33.11 & 0.02 & 0.02 & 0.02 \\
\hline f. Metric, angle, direction measures & 12.22 & 11.74 & 49 & 0.02 & 0.02 & 0.03 \\
\hline g. Locational adverbs and prepositions & 19.22 & 19.05 & 68.61 & 0.04 & 0.03 & 0.04 \\
\hline h. Metadiscoursal refs. to visual data & 3 & 5.21 & 24.14 & 0.01 & 0.01 & 0.01 \\
\hline i. Geographical location & 13.28 & 13.53 & 47.61 & 0.03 & 0.02 & 0.03 \\
\hline j. Own prior publications & 4.06 & 3.44 & 7.54 & 0.01 & 0.01 & 0.00 \\
\hline \multicolumn{7}{|l|}{ Move 3 Cues } \\
\hline k. Nominal \& adjectival field qualifiers & 153.72 & 148.37 & 421.29 & 0.30 & 0.26 & 0.25 \\
\hline 1. Geological age & 10.39 & 5.42 & 21.04 & 0.02 & 0.01 & 0.01 \\
\hline m. Verbal adjectives and participles & 18.83 & 23.05 & 63.46 & 0.04 & 0.04 & 0.04 \\
\hline n. References to others' fieldwork & 6.39 & 5 & 13.5 & 0.01 & 0.01 & 0.01 \\
\hline
\end{tabular}

$(\mathrm{FA}=$ field account GC $=$ Geochemistry, $\mathrm{P}=$ Petrology, $\mathrm{SG}=$ Structural Geology, $\mathrm{n}=67,758$ words $)$

\section{References}

Atkinson, D. (1999). Scientific discourse in sociohistorical context: The philosophical transactions of the Royal Society of London. Mahwah, NJ: Lawrence Erlbaum, pp. 1675-1975.

Anderson, J., Reder, L., \& Simon, H. (1998). Radical constructivism and cognitive psychology. In D. Ravitch (Ed.), Brookings papers on education policy (pp. 227-278). Washington, DC: Brookings Institution Press.

Bazerman, C. (1988). Shaping written knowledge: The genre and activity of the experimental article in science. Madison: University of Wisconsin Press.

Bazerman, C. (1994). Systems of genres and the enactment of social intentions. In A. Freedman \& P. Medway (Eds.), Genre and the new rhetoric (pp. 79-101). Bristol, PA: Taylor \& Francis.

Bazerman, C. (1997). The life of genre, the life in the classroom. In W. Bishop \& H. Ostrum (Eds.), Genre and writing (pp. 1926). Portsmouth, NH: Boynton/Cook.

Bering Strait Geologic Field Party (1997). Koolen metamorphic complex, NE Russia: Implications for the tectonic evolution of the Bering Strait region. Tectonics, 16, 713-729.

Berkenkotter, C., \& Huckin, T. (1995). Genre knowledge in disciplinary communication: Cognition, culture, power. Hillsdale, NJ: Lawrence Erlbaum.

Bittencourt-Santos, M. (1996). The textual organization of research paper abstracts in Applied Linguistics. Text, 16, 481-499.

Bourdieu, P. (1984). Distinction: A social critique of the judgment of taste. Harvard: Harvard University Press.

Bunton, D. (1999). The use of higher level metatext in Ph.D. theses. English for Specific Purposes, 18, 41-56.

Devitt, A. (2004). Writing genres. Carbondale: Southern Illinois University.

Dressen, D. (2002a). Accounting for fieldwork in three areas of modern geology: A situated analysis of textual silences and saliences. The University of Michigan, Ann Arbor: Unpublished PhD dissertation.

Dressen, D. (2002b). Textual silence in scientific research articles: Recontextualizations of the field account in geology. Hermes: Journal of Language and Communication Studies, 28, 81-107. 
Dressen, D. (2003). Geologists' implicit persuasive strategies and the construction of evaluative evidence. Journal of English for Academic Purposes, 2, 273-290.

Dressen, D., \& Swales, J. M. (2000). "Geological setting/cadre géologique” in English and French petrology articles: Muted indications of explored places. In A. Trosberg (Ed.), Analysing professional genres (pp. 57-76). Amsterdam: Benjamin.

Ericsson, K. (Ed.). (1996). The road to excellence: The acquisition of expert performance in the arts and science, sports and games. Mahwah, NJ: Erlbaum.

Fairclough, N. (1992). Discourse and social change. Cambridge: Polity Press.

Fillmore, C. (1985). Frames and the semantics of understanding. Quaderni di Semantica, 6, 222-254.

Freedman, A., \& Medway, P. (Eds.). (1994). Genre in the new rhetoric. London: Taylor \& Francis

Gonçalvez, P., Nicollet, C., \& Lardeaux, J.-M. (2003). Later Neoproterozoic strain pattern in the Andriamena unit (North-Central Madagascar): Evidence for thrust tectonics and cratonic convergence. PreCambrian Research, 123, 135-157.

Goodwin, C. (2000). Action and embodiment within situated human interaction. Journal of Pragmatics, 32, 1489-1522.

Hindmarsh, J., \& Heath, C. (2000). Embodied reference: A study of deixis in workplace interaction. Journal of Pragmatics, 32 , $1855-1878$.

Huckin, T. (2002). Textual silences and the discourse of homelessness. Discourse and Society, 13, 347-372.

Hyland, K. (2002). Authority and invisibility: Authorial identity in academic writing. Journal of Pragmatics, 34, 1091-1112.

Ivanic, R. (1998). Writing and identity: The discoursal construction of identity in academic writing. Amsterdam: John Benjamins.

Lakoff, G., \& Johnson, M. (1999). Philosophy in the flesh. New York: Basic Books.

Matsuda, P., \& Tardy, C. (2007). Voice in academic writing: The rhetorical construction of author identity in blind manuscript review. English for Specific Purposes, 26, 235-249.

Medway, P. (2002). Fuzzy genres and community identities: The case of architecture students' sketchbooks. In R. Coe, L. Lingard, \& T. Teslenko (Eds.), The rhetoric and ideology of genre (pp. 123-154). Cresskill, NJ: Hampton.

Merle, O., Cobbold, P., \& Schmid, S. (1989). Tertiary kinematics in the Lepontine dome. Alpine Tectonics, 45, $113-134$.

Miller, C. (1984). Genre as social action. Quarterly Journal of Speech, 70, 151-167.

Minsky, M. (1975). A framework for representing knowledge. In P. Winston (Ed.), The psychology of computer vision. New York: McGraw-Hill.

Paltridge, B. (2002). Thesis and dissertation writing: An examination of published advice and actual practice. English for Specific Purposes, 21, 125-143

Räisänen, C. (2002). The conference forum: A system of interrelated genres and discursive practices. In E. Ventola, C. Shalom, \& S. Thompson (Eds.), The language of conferencing (pp. 69-93). Frankfurt: Peter Lang.

Roth, W. M. (2004). Perceptual gestalts in workplace communication. Journal of Pragmatics, 36, 1037-1069.

Rudwick, M. (1985). The Great Devonian Controversy: The shaping of scientific knowledge among gentlemanly specialists. Chicago: University of Chicago Press.

Russell, D. (1997). Rethinking genre in school and society: An activity theory analysis. Written Communication, 14, 504-554.

Salager-Meyer, F. (1998). Le discours aigre-doux de la controverse scientifique: Evolution de la rhétorique des confrontations acade miques. Asp, la revue du GERAS, 19/22, 29-50.

Schryer, C. (1993). Records as genre. Written Communication, 10, 200-234.

Schryer, C., \& Spoel, P. (2005). Genre theory, health-care discourse, and professional identity formation. Journal of Business and Technical Communication, 19, 249-278.

Shaw, P. (2000). Towards classifying the arguments in research genres. In A. Trosberg (Ed.), Analysing professional genres (pp. 41-56). Amsterdam: John Benjamins.

Stubbs, M. (2001). On inference theories and code theories: Corpus evidence for semantic schemas. Text, 21, 437-465.

Swales, J. M. (1990). Genre analysis: English in academic and research settings. Cambridge: Cambridge University Press.

Swales, J. M. (2004). Research genres: Explorations and applications. Cambridge: Cambridge University Press.

Swales, J. M., \& Lindemann, S. (2002). Teaching the literature review to international graduate students. In A. Johns (Ed.), Genres and the classroom - Multiple perspectives (pp. 105-119). Mahwah, NJ: Lawrence Erlbaum.

Tannen, D. (1993). What's in a frame? Surface evidence for underlying expectations. In D. Tannen (Ed.), Framing in discourse (pp. 14-56). Oxford: Oxford University Press.

Tannen, D., \& Wallet, C. (1993). Interactive frames and knowledge schemas in interaction: Examples from a medical examination/interview. In D. Tannen (Ed.), Framing in Discourse (pp. 57-76). Oxford: Oxford University Press.

van Leeuwen, T. (1999). Speech, music, sound. London: Macmillan.

Yakhontova, T. (1998). Cultural variation in the genre of the conference abstract: rhetorical and linguistic dimensions. Paper presented at the Conference on English as a conference language, Halle-Wittenberg, Germany, 14-17 January 1998.

Yule, G. (1996). Pragmatics. Oxford: Oxford University Press. 